\title{
Sharing experience through case reports
}

\author{
Fernando Peixoto Ferraz de Campos ${ }^{a}$
}

Campos FPF. Sharing experience through case reports [editorial]. Autopsy Case Rep [Internet]. 2012;2(2):1-3. http://dx.doi.org/10.4322/acr.2012.010

Even before the time of Hippocrates, case reports have provided rich resources for teaching and research in medicine,,$^{1,2}$ despite the disparaging attention given by the scientific community to these reports in comparison with other types of publications. Not only have clinicians been learning from their more experienced peers, but also from their own work with their individual patients for a very long time. Accurate recounting of clinical experience continues to be essential to the progress of medicine, even in the modern era of evidence-based medicine, where, in the pinnacle of this hierarchy, are found the randomized clinical trials, systematic reviews and meta-analysis. ${ }^{3,4,5}$

Shunned by some, adored by others, case reports are sometimes regarded by researchers and physicians as anecdotal descriptions, underestimating their value and importance. However, few of them know that the Greek word for anecdote (anekdota) means "unpublished;" and according to the Oxford Dictionary one of the meanings is the narrative of an interesting or striking incident or event case. ${ }^{2}$

Nathan (1967) pointed out several case reports that have become famous and important in the history of medicine, as the case of Phineas Gage, the man who had a four-foot iron bar blown through his frontal lobes and whose immortal remains are now in the Harvard Museum. The importance of this "striking incident or event" was not grasped at the time. Had it been realized that one could interfere with large masses of the cerebral hemispheres without killing the patient, and that great damage to the frontal lobes need cause no obvious intellectual defect, neurosurgery might have been conceived 40 years earlier. The frontal lobes were believed to be the seat of all intellectual activities, and their relation to personality was not known at the time, although Phineas Gage showed some astounding changes in this respect. ${ }^{2}$

At the turn of the last century, Sir William Osler, author of many scientific observations, ever encouraged other physicians to record and publish the unusual. ${ }^{1,6,7}$

In 1981, a case report published in the American Journal of Dermatopathology was the first published account of what is now called AIDS. ${ }^{8}$ Another recent and prominent example of the usefulness of case reports in clinical medicine was the publication of a case series during the outbreak of Shiga-toxin producing Escherichia coli, a type of enterohemorrhagic E. coli, in Germany in mid-2011.9,10

Case reports can describe important scientific observations that are missed or undetectable in clinical trials; provide insightful information that expands our knowledge and spawns new research; and provide information that strays from the classical textbook and leads to better and safer patient care. ${ }^{11}$

Notwithstanding the plurality of evidence and benefits that case reports bring to the scientific community, it appears that there is a lack of enthusiasm by the novice doctors to devote part of their time to produce and share their knowledge. We believe that even the most experienced doctors show

a Hospital Universitário - Universidade de São Paulo - São Paulo/SP - Brazil.

Copyright $\odot 2012$ Autopsy and Case Reports - This is an Open Access article distributed of terms of the Creative Commons Attribution NonCommercial License (http://creativecommons.org/licenses/by/3.0/) which permits unrestricted non-commercial use, distribution, and reproduction in any médium provided article is properly cited. 
little interest or initiative to engage in this activity. Likewise, some renowned periodicals, with a high impact index, do not drive the same emphasis to publish case reports and their acceptance process takes many twists and turns until the paper fits their requirements. Journals that do publish case reports are very demanding on several criteria, especially that of uniqueness. Novelty is a criterion commonly cited by authors and editors when validating the importance of a case report. However, a truly unique case is a rare event in clinical practice, and by focusing solely on novelty, many novice authors de-emphasize the educational value of their reports. ${ }^{9}$

Cases that increase the awareness of an unusual condition, describe a rare presentation of a common condition, or identify innovative treatment and diagnostic strategies are valuable additions to the medical literature whether they are novel or not. ${ }^{9,12}$ Nathan pointed out that although an observation may be uncommon, unless it is reported, the frequency of its occurrence cannot be tabulated. $^{2}$

A case report can thus be defined and judged by the importance, clarity, and practicality of its educational message. ${ }^{7}$ When one case has been reported, other doctors become aware of the complication and look out for it; thus, the frequency of the complication can eventually be assessed. Sometimes we think that something we have observed or learned from a patient is unique, whereas, in fact, it is uncommon but not unique.

Case reports can serve several purposes: they offer their readers a recognition pattern to identify similar rare cases in their own practices; they alert readers to new and rare adverse reactions to drugs; and they highlight innovations in medical management, dilemmas in medical ethics, and progress in medical education. ${ }^{9}$ Given the broad range of topics that can be legitimately highlighted in a case report, there may be many instances during one's medical career when it may be appropriate to write a case report.

When reporting clinical cases, the author faces some barriers. Some consider the greatest to be lack of time in the doctor's life, followed by the unfamiliarity with the publication process. Indeed, this process requires time, will and determination. The main obstacle for publication is the intimidation caused by the physician's self-assessment of his incapacity for this task, followed by ignorance of the demands of the process. Moreover, the inertia needs to be overcome. Many doctors would like to engage in great scientific projects, for which they are not properly qualified or trained. Frustrated with the inability to develop them, they forget they could focus on more achievable publications.

Case reports are also important educational tools to both authors and readers. These reports often serve as a clinician's first experience with scholarly writing and provide an important training ground in manuscript preparation and publication. ${ }^{9}$

Every medical student, resident, or novice doctor, should be encouraged and guided toward scientific production, which should include publications such as case reports, review, and research articles. This represents a unique opportunity to gain experience in scientific writing and learn from their clinical mentors. Medical schools and related educational institutions should require their teachers to encourage and guide the beginners in this manner.

Autopsy and Case Reports is an electronic medical journal that shares the same opinion, encouraging the medical community to publish clinical case reports, autopsy case reports, and surgical pathology case reports.

\section{REFERENCES}

1. McCarthy LH, Reilly KEH. How to write a case report. Fam Med. 2000;32:190-5. PMid:10726220.

2. Nathan PW. When is an anecdote? Lancet. 1967;2:607. http://dx.doi.org/10.1016/S0140-6736(67)907544

3. Jenicek M. Clinical case reporting in evidence-based medicine. 2nd ed. London: Arnold; 2001.

4. Kidd M, Hubbard C. Introducing Journal of Medical Case Reports. J Med Case Reports. 2007;1:1. PMid:17411446 PMCid:1839763. http://dx.doi.org/10.1186/1752-1947-1-1

5. Yitschaky O, Yitschaky M, Zadik Y. Case report on trial: Do you, Doctor, swear to tell the truth, the hole truth and nothing but the truth? J Med Case Reports. 2011;5:179. PMid:21569508 PMCid:3113995. http://dx.doi.org/10.1186/1752-1947-5-179

6. Coccia CT, Ausman JI. Is a case report an anecdote? In defense of personal observations in medicine. Surg Neurol. 1987;28:111-3. http://dx.doi.org/10.1016/00903019(87)90082-6 
7. Chelvarajah R, Bycroft J. Writing and publishing case reports: the road to success. Acta Neurochir (Wien). 2004;146:313-6 PMid:15015057. http://dx.doi.org/10.1007/s00701-003-0203-2

8. Gottlieb GJ, Rogoz A, Vogel JV, et al. A preliminary communication on extensively disseminated Kaposi's sarcoma in a young homosexual man. Am J Dermatopathol. 1981;3:1114. PMid:7270808. http://dx.doi.org/10.1097/00000372198100320-00002

9. Carleton HA, Webb ML. The case report in context [editorial]. Yale J Biol Med. 2012;85:93-6. PMid:22461747 PMCid:3313543.

Correspondence: Fernando Peixoto Ferraz de Campos Scientific Editor Autopsy and Case Reports Assistant Physician of Internal Medicine Division Hospital Universitário - Universidade de São Paulo, São Paulo/SP - Brazil E-mail: ffcampos@usp.br
10. Frank C, Werber D, Cramer JP, et al. Epidemic profile of Shiga-toxin-producing Escherichia coli O104:H4 outbreak in Germany. N Engl J Med. 2011;365:1771-80. PMid:21696328. http://dx.doi.org/10.1056/NEJMoa1106483

11. Cohen H. How to write a patient case report. Am J HealthSyst Pharm. 2006; 63:1888-92. PMid:16990637. http:// dx.doi.org/10.2146/ajhp060182

12. Vandenbroucke JP. Case reports in an evidence-based world. J R Soc Med. 1999;92:159-63. PMid:10450190 PMCid:1297135. 
